УДК 351.7.3.862.4+618.4

Гур'єв Сергій,

д-р мед. наук, проф.,

ORCID iD 0000-0003-0191-945X

E-mail: disastermed@ukrpost.ua

Іскра Наталія,

д-р мед.наук, доц.

Терент'сва Анна,

д-р держ. упр., проф.,

ORCID iD 0000-0003-3881-5865

E-mail: teren_a@ukr.net

\title{
ІНФОРМАЦІЙНА ВЗАЕМОДІЯ В УМОВАХ НАДЗВИЧАЙНИХ СИТУАЦІЙ МЕДИКО-БІОЛОГІЧНОГО ХАРАКТЕРУ
}

\author{
https://doi.org/10.32689/2618-0065-2020-4(6)-68-92
}

\begin{abstract}
Анотація. Базовим ресурсом для здійснення управлінської діяльності, зокрема опрацювання управлінських рішень, $є$ адекватна інформація про надзвичайну ситуацію як власне подію та ï характеристики. Саме на цій інформації грунтуються наступні заходи щодо здійснення управлінських функцій: оцінка обстановки в зоні надзвичайної ситуації, прийняття управлінського рішення, планування дій, організація взаємодії і кризових комунікацій, постановка завдань до виконання та здійснення контролю прийнятих управлінських рішень. Проблема отримання адекватної та своєчасної інформації про наслідки надзвичайної ситуації безпосередньо із-зони для прийняття управлінських рішень частіше за все виникає з причини відсутності налагоджених процедур отримання та обміну інформацією між всіма службами екстреного реагування, що залучаються до надання допомоги постраждалим. Вирішення цієї проблеми можливе лише за наявності консолідованих підходів до класифікації надзвичайної ситуації, методик визначення поворотних і безповоротних санітарних втрат і розрахунку сил і засобів, що залучаються до ліквідації наслідків надзвичайної ситуації. Метою взаємодії ДСНС і МОЗ з попередження та ліквідації медико-санітарних наслідків надзвичайної ситуації $\epsilon$ забезпечення
\end{abstract}




\section{Науковий вісник: Державне управління № 4(6)2020}

ефективного використання медичного персоналу, спеціалізованого санітарного транспорту, медичних виробів, лікарських засобів, закладів охорони здоров'я для рятування життя та збереження здоров'я людей під час ліквідації медико-санітарних наслідків надзвичайної ситуації.

Ключові слова: інформаційна взаємодія, управління, наслідки, надзвичайна ситуація, повідомлення.

Постановка проблеми. Сучасний розвиток України за умов системної трансформації характеризується як перманентно складний, а часом навіть із провалами екстремальності. Глобальний розвиток людської цивілізації, крім позитивних надбань, породив чисельні загрози життєво важливим інтересам людини і громадянина, суспільства i держави. Значне місце серед цих загроз займають небезпеки техногенно-природної сфери. Багато з них у тій, чи іншій мірі притаманні й Україні. У зв'язку з цим, велика роль у забезпеченні техногенної та природної безпеки відводиться саме Єдиній державній системі цивільного захисту населення і територій.

Цілісний захист здійснюється з метою реалізації державної політики, спрямованої на забезпечення безпеки та захисту населення територій, матеріальних і культурних цінностей та довкілля від негативних наслідків надзвичайних ситуацій (НC) у мирний час та особливий період, ліквідації наслідків НС, зокрема наслідків НС на територіях іноземних держав відповідно до міжнародних договорів України, згода на обов'язковість яких надана Верховною Радою України.

Ризики виникнення НС природного i техногенного характеру $є$ фактором, що визначає якість життя у регіонах будь-якої країни. На жаль, для України ці ризики є достатньо високими, що зумовлює нагальну потребу докладного опрацювання організаційно-управлінських підходів до вирішення цієї комплексної проблеми. Все вищевикладене зумовлює визнання того, що традиційні підходи до управління ліквідацією комплексних наслідків НС, як доводить досвід їх 
застосування, часто призводять до незадовільних результатів. Також серйозною проблемою організації ефективного управління за умов НС є реальне ускладнення або відсутність координації дій офіційних урядових, відомчих і неурядових органів управління, а також налагодження міжвідомчої інформаційної взаємодії.

Вивчення наявних наукових досліджень проблематики інформаційної взаємодії в умовах НС медико-біологічного характеру підтверджує наявність розрізнених досліджень, зосереджених на вивченні окремих аспектів реагування на НC, зокрема надання домедичної допомоги та функціонування мобільних медичних формувань служби медицини катастроф. Наразі відсутнє комплексне дослідження, в якому було пов'язано необхідність отримання адекватної своєчасної управлінської інформації безпосередньо із зони НС та специфіки функціонування інформаційно-аналітичних систем у сфері цивільного захисту. Вище викладене зумовило актуальність даної публікації.

\section{Аналіз останніх досліджень і публікацій. У} попередніх наукових дослідженнях узагальнено та систематизовано теоретичні та методологічні положення, що надають прийняттю рішень характеру науково обгрунтованого процесу, досліджено базові моделі науково обгрунтованого управління в соціальних системах [1], розглянуто питання забезпечення прийняття органами державного управління обгрунтованого рішення щодо застосування сил і засобів цивільного захисту за рахунок удосконалення інформаційного забезпечення [2, 3], запропоновано науково-методичний апарат вибору найбільш раціонального рішення на застосування сил і засобів цивільного захисту [4], досліджено критерії оцінювання ефективності функціонування органів державного управління у НC [5], досліджено проблемні питання щодо організації робо-ти органів управління у НС [6], досліджено послідовність та зміст роботи керівника органу 
Науковий вісник: Державне управління № 4(6)2020

управління у НС, запропоновано модель процесу управління під час реагування на НС [7].

Категорію «Інформаційно-аналітичне забезпечення органів публічної влади» всебічно досліджено в роботі [8] та визначено вимоги до управлінської інформації.

Більш докладно функціональну структуру інформаційноаналітичної системи органу публічної влади запропоновано у роботі [9], де особливо виокремлюється підсистеми збору i подання інформації та аналізу і прогнозування.

Але наукового завдання щодо інформаційної взаємодії в умовах НС медико-біологічного характеру комплексно не вирішувалося.

Мета статті. Увагу зосереджено на всебічному вивченні проблеми інформаційної взаємодії в умовах НС медикобіологічного характеру, визначенні іï специфіки та шляхів удосконалення для покращення реагування на НС.

Виклад основного матеріалу. Проблеми ефективного та адекватного захисту населення, яке постраждало внаслідок НС є одним 3 актуальних завдань цивільного захисту, що зумовлено двома причинними факторами: по-перше, зростанням частоти та важкості НС, по-друге, виникненням нових типів НС, зокрема соціально-політичного характеру, що потребує особливого характеру організації процесу ліквідації наслідків НС.

Для ефективного функціонування системи запобігання та реагування на НС природного та техногенного характеру потрібна своєчасна, безперервна, повна та достовірна інформація, без якої важко оцінити обстановку, можливості сил та засобів служб, призначених для запобігання та ліквідації НС, координувати їх зусилля.

Базовим ресурсом для здійснення управлінської діяльності, зокрема опрацювання управлінських рішень, $\epsilon$ адекватна інформація про НС як власне подію та іiі характеристики. Саме на цій інформації грунтуються наступні заходи щодо здійснення управлінських функцій: оцінка 
обстановки в зоні НС, прийняття управлінського рішення, планування дій, організація взаємодії і кризових комунікацій, постановка завдань до виконання та здійснення контролю прийнятих управлінських рішень.

Проблема актуальності та адекватності інформації, що характеризує обстановку в зоні НС, багато в чому залежить від часового і людського фактору, що може значно ускладнити прийняття правильного управлінського рішення у мовах $\mathrm{HC}[10]$.

Слід зауважити, що інформація у сфері захисту населення й територій від НС техногенного та природного характеру, діяльність центральних та місцевих органів виконавчої влади, виконавчих органів рад у цій сфері $є$ гласною і відкритою, якщо інше не передбачено законом.

3 метою інформаційно-аналітичного забезпечення процесів підготовки, прийняття та контролю виконання рішень 3 питань НС створена в масштабах держави Урядова інформаційно-аналітична система 3 питань НС (УІАС НC), основним призначенням якої $\epsilon$ забезпечення Кабінету Міністрів України та інших органів виконавчої влади достовірною інформацією щодо екологічної безпеки, факторів ризику виникнення НС, а при виникненні НС - про ії наслідки, хід робіт з ліквідації наслідків НС [11].

Класифікатор надзвичайних ситуацій ДК 019:2010 [12] визначає НC як порушення нормальних умов життя та діяльності людей на окремій території чи об'єкті на ній або на водному об'єкті, спричинене аварією, катастрофою, стихійним лихом чи іншою небезпечною подією, зокрема епідемією, епізоотією, епіфітотією, пожежею, що призвело (може призвести) до виникнення великої кількості постраждалих, загрози життю та здоров'ю людей, їх загибелі, значних матеріальних утрат, а також до неможливості проживання населення на території чи об'єкті, ведення там господарської діяльності. 
Науковий вісник: Державне управління № 4(6)2020

Згідно Класифікатору НС ДК 019:2010 до НС медикобіологічного характеру відносяться (табл. 1).

Таблиця 1 - НС медико-біологічного характеру

\begin{tabular}{|l|l|}
\hline 0700 & \multicolumn{1}{|c|}{ Медико-біологічні НС } \\
\hline 20710 & НС, пов'язані з інфекційним захворюванням людей \\
\hline 20711 & $\begin{array}{l}\text { НС, пов'язана з екзотичним та особливо небезпечним } \\
\text { інфекційним захворюванням людей (окремі випадки) }\end{array}$ \\
\hline 20712 & $\begin{array}{l}\text { НС, пов'язана з небезпечною інфекційною хворобою (групові } \\
\text { випадки) }\end{array}$ \\
\hline 20714 & $\begin{array}{l}\text { НС, пов'язана з епідемічним спалахом небезпечних інфекційних } \\
\text { хвороб }\end{array}$ \\
\hline 20715 & ПС, пов'язана з епідемією \\
\hline 20716 & $\begin{array}{l}\text { НС, пов'язана 3 інфекційним захворюванням людей } \\
\text { невизначеної етіології }\end{array}$ \\
\hline 20720 & НС, пов'язані з отруєнням людей \\
\hline 20721 & $\begin{array}{l}\text { НС, пов'язана 3 отруєнням людей у результаті споживання } \\
\text { неякісних продуктів харчування }\end{array}$ \\
\hline 20722 & $\begin{array}{l}\text { НС, пов'язана 3 отруєнням людей у результаті споживання } \\
\text { неякісної питної води }\end{array}$ \\
\hline 20723 & $\begin{array}{l}\text { НС, пов'язана 3 отруєнням людей токсичними або іншими } \\
\text { речовинами (окремі випадки) }\end{array}$ \\
\hline 20724 & $\begin{array}{l}\text { НС, пов'язана 3 отруєнням людей токсичними або іншими } \\
\text { речовинами (групові випадки) }\end{array}$ \\
\hline 20725 & $\begin{array}{l}\text { НС, пов'язана з отруєнням людей токсичними або іншими } \\
\text { небезпечними речовинами (масові випадки) }\end{array}$ \\
\hline
\end{tabular}

Також визначено, що НС природного характеру порушення нормальних умов життя та діяльності людей на окремій території чи об'єкті на ній або на водному об'єкті, пов'язане 3 небезпечним геофізичним, геологічним, метеорологічним або гідрологічним явищем, деградацією грунтів чи надр, пожежею у природних екологічних системах, зміною стану повітряного басейну, інфекційною захворюваністю та отруєнням людей, інфекційним захворюванням свійських тварин, масовою загибеллю диких тварин, ураженням сільськогосподарських рослин хворобами та шкідниками тощо. 
Відповідно до Кодексу цивільного захисту [13] НС обстановка на окремій території чи суб’єкті господарювання на ній або водному об'єкті, яка характеризується порушенням нормальних умов життєдіяльності населення, спричинена катастрофою, аварією, пожежею, стихійним лихом, епідемією, епізоотією, епіфітотією, застосуванням засобів ураження або іншою небезпечною подією, що призвела (може призвести) до виникнення загрози життю або здоров'ю населення, великої кількості загиблих i постраждалих, завдання значних матеріальних збитків, а також до неможливості проживання населення на такій території чи об'єкті, провадження на ній господарської діяльності.

Відповідно до Класифікаційних ознак надзвичайних ситуацій» [14] проведено класифікацію НC медикобіологічного характеру (табл. 2).

Наразі інфекційні хвороби не лише проблема життя та здоров'я людини, але й важлива соціально-економічна проблема, що має наслідки для благополуччя як окремої людини так й держави в цілому. Інфекційна захворюваність викликає занепокоєння не лише своєю поширеністю, а також через загрозу, що вона становить здоров'ю громадян, економіці країни, іміджу держави.

Протягом останніх років щороку з причини інфекційних захворювань за медичною допомогою в Україні звертається 8-9 млн. осіб.

Проблема отримання адекватної та своєчасної інформації про наслідки НC безпосередньо із-зони для прийняття управлінських рішень частіше за все виникає 3 причини відсутності налагоджених процедур отримання та обміну інформацією між всіма службами екстреного реагування, що залучаються до гадання допомоги постраждалим. Вирішення цієї проблеми можливе лише за наявності консолідованих підходів до класифікації НС, методик визначення поворотних і безповоротних санітарних втрат і розрахунку сил і засобів, що залучаються до ліквідації наслідків НС. 


\section{Таблиия 2 - Класифікація НС медико-біологічного характеру}

\begin{tabular}{|c|c|c|c|c|}
\hline $\begin{array}{l}\text { № } \\
\text { 3/ } \\
\text { ח }\end{array}$ & $\begin{array}{c}\text { Опис ознаки } \\
\text { (короткий опис ситуації, випадку, } \\
\text { події, аварії, явища) }\end{array}$ & $\begin{array}{c}\text { Одиниця } \\
\text { виміру } \\
\text { показника } \\
\text { ознаки }\end{array}$ & $\begin{array}{c}\text { Порогове } \\
\text { значення } \\
\text { показника } \\
\text { ознаки }\end{array}$ & Примітка \\
\hline 1 & 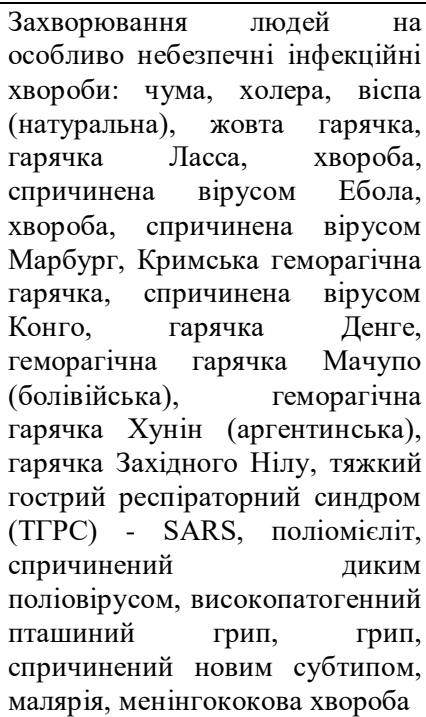 & Особа & Від 1 & $\begin{array}{l}\text { Перелік } \\
\text { нозологічних форм } \\
\text { інфекційних } \\
\text { хвороб, що мають } \\
\text { міжнародне } \\
\text { значення [17] }\end{array}$ \\
\hline 2 & $\begin{array}{l}\text { Захворювання людей на } \\
\text { особливо небезпечні інфекційні } \\
\text { хвороби: сибірка, сказ, } \\
\text { туляремія, бруцельоз, гарячка } \\
\text { Ку, лістеріоз, трихінельоз, } \\
\text { кліщовий енцефаліт, } \\
\text { лейшманіоз }\end{array}$ & Особа & Від 1 & $\begin{array}{l}\text { Перелік } \\
\text { нозологічних форм } \\
\text { інфекційних } \\
\text { хвороб, що мають } \\
\text { міжнародне } \\
\text { значення [17] }\end{array}$ \\
\hline 3 & $\begin{array}{l}\text { Захворювання людей на } \\
\text { особливо небезпечні інфекційні } \\
\text { хвороби: лептоспіроз, орнітоз }\end{array}$ & Особа & $\begin{array}{l}\text { Від } 5 \\
\text { протягом } \\
3 \text { днів }\end{array}$ & \\
\hline
\end{tabular}


Науковий вісник: Державне управління № 4(6)2020

\begin{tabular}{|c|c|c|c|c|}
\hline 5 & $\begin{array}{l}\text { Захворювання людей на } \\
\text { небезпечні інфекційні хвороби: } \\
\text { шигельоз (дизентерія) та інші } \\
\text { гострі кишкові інфекційні } \\
\text { захворювання встановленої та } \\
\text { невстановленої етіології, } \\
\text { сальмонельоз, вірусний } \\
\text { гепатит А }\end{array}$ & Особа & $\begin{array}{l}\text { Від } 5 \text { - в } \\
\text { організов. } \\
\text { колективах } \\
\text { (від } 10 \text { - } \\
\text { серед } \\
\text { населення) } \\
\text { протягом } 3 \\
\text { днів }\end{array}$ & \\
\hline 6 & $\begin{array}{l}\text { Перевищення порогового рівня } \\
\text { захворюваності людей на грип, } \\
\text { гострі респіраторні вірусні } \\
\text { захворювання удвічі і більше } \\
\text { разів протягом періоду понад } 2 \\
\text { тижні у двох та більше } \\
\text { адміністративних районах } \\
\text { області (Автономна Республіка } \\
\text { Крим, міста Київ та } \\
\text { Севастополь), містах або в } \\
\text { цілому по країні }\end{array}$ & Факт & 1 & \\
\hline 7 & $\begin{array}{l}\text { Інфекційні захворювання людей } \\
\text { невиявленої етіології } \\
\text { (гарячковий стан більше } 5 \text { днів } \\
\text { та/або пронос більше } 5 \text { раз на } \\
\text { добу протягом } 3 \text { днів) }\end{array}$ & Особа & Від 10 & \\
\hline 8 & $\begin{array}{l}\text { Отруєння людей хімічними або } \\
\text { токсичними речовинами } \\
\text { військового походження }\end{array}$ & Факт & 1 & \\
\hline 9 & $\begin{array}{l}\text { Випадок отруєння від } 10 \text { людей } \\
\text { НХР, що використовуються на } \\
\text { виробництві, або іншими } \\
\text { небезпечними речовинами }\end{array}$ & Особа & - " - & $\begin{array}{l}\text { Від } 10 \text { - окреме, } \\
\text { від } 26 \text { - групове, } \\
\text { від } 101 \text { - масове }\end{array}$ \\
\hline 10 & $\begin{array}{l}\text { Одночасне отруєння людей } 3 \\
\text { одного колективу внаслідок } \\
\text { споживання продуктів } \\
\text { харчування або води: } \\
\text { ботулізм } \\
\text { токсиканти одного виду } \\
\text { дикорослі гриби та рослини або } \\
\text { комбінація токсикантів двох і } \\
\text { більше видів }\end{array}$ & Особа & $\begin{array}{l}\text { Від } 1 \\
\text { Від } 10 \\
\text { Від } 5\end{array}$ & \\
\hline 11 & $\begin{array}{l}\text { Випадок отруєння від } 5 \text { людей } \\
\text { невстановленою речовиною } \\
\text { (отрутою) }\end{array}$ & Факт & 1 & $\begin{array}{l}\text { Від } 5 \text { - окреме, } \\
\text { від } 11 \text { - групове, } \\
\text { від } 51 \text { - масове }\end{array}$ \\
\hline
\end{tabular}


Науковий вісник: Державне управління № 4(6)2020

Дане питання потребує певного унормування, що було проведено 3 урахуванням попереднього досвіду взаємодії оперативних підрозділів служби цивільного захисту та мобільних медичних формувань служби медицини катастроф.

Порядок подання інформації про виникнення НС встановлений «Регламентом подання інформації у функціональній підсистемі Міністерства охорони здоров'я України в межах Урядової інформаційно-аналітичної системи 3 питань надзвичайних ситуацій», затвердженим наказом МO3 України від 03.08.2000 за № 189.

Регламентом встановлено порядок інформаційної взаємодії МО3 України, управлінь охорони здоров'я обласних держадміністрацій (далі - територіальні органи управління охорони здоров'я - ТОУОЗ) та установ і закладів охорони здоров'я при виникненні або загрозі виникнення НС техногенного і природного характеру, ліквідації медикосанітарних наслідків НС.

Також визначено організацію структури функціональної підсистеми МОЗ України в межах УІАС НС.

Основними завданнями інформаційної взаємодії центрального вузла інформаційно-аналітичного оброблення інформації УІАС НC у Кабінеті Міністрів України (центральний вузол УІАС $\mathrm{HC}$ ), та резервного вузла інформаційно-аналітичного оброблення інформації УІАС НС у МНС України (зараз - ДСНС України) (резервний вузол УІАС НC) через вузол інформаційно-аналітичного оброблення інформації УІАС НС у МОЗ України (вузол МОЗ України) є: збирання, накопичення та аналітичне оброблення інформації про наслідки $\mathrm{HC} 3$ вузлів інформаційно-аналітичного оброблення інформації УІАС УОЗ (вузли ТОУОЗ) та закладів охорони здоров'я; забезпечення постійного зв'язку та обміну інформацією між центрами УІАС НС, резервним вузлом УІАС НC, вузлом МO3 України, вузлами ТОУО3, закладами охорони здоров'я. 
Науковий вісник: Державне управління № 4(6)2020

MO3 України затверджені терміни надання інформації про виникнення (загрозу виникнення) НC та іiі медико-санітарні наслідки залежно від іiі рівня (табл. 3) відповідно до наказу MO3 України від 30.07.2009 № 560 «Про додаткові заходи щодо підвищення рівня інформаційного забезпечення ліквідації медико-санітарних наслідків надзвичайних ситуацій природного техногенного характеру» [15]. Також визначені терміни надання інформації та стандартизовано форми повідомлень.

«Екстрене повідомлення про надання медичної допомоги при надзвичайній ситуації (НС)» (форма № 155/0) є медичним обліковим документом, що призначається для попередньої інформації всіх суб'єктів функціональної підсистеми охорони УІАС НС, кількість, стан постраждалих та кількість загиблих при $\mathrm{HC}$, про медичні формування (заклади), які приймають участь в ліквідації наслідків НС.

Таблиця 3 - Терміни надання інформації

\begin{tabular}{|l|c|c|c|c|}
\hline \multicolumn{1}{|c|}{ Рівень НС } & $\begin{array}{c}\text { Черговому } \\
\text { ЦРЛ або } \\
\text { ЦМЛ }\end{array}$ & $\begin{array}{c}\text { Вузол } \\
\text { ТОУО3 }\end{array}$ & $\begin{array}{c}\text { Вузол } \\
\text { МО3 } \\
\text { України }\end{array}$ & $\begin{array}{c}\text { Центральний } \\
\text { і резервний } \\
\text { вузол } \\
\text { УІАС НС }\end{array}$ \\
\hline загальнодержавний & 15 хв. & 25 хв. & 45 хв. & 55 хв. \\
\hline регіональний & 15 хв. & 25 хв. & 45 хв. & 55 хв. \\
\hline місцевий & 15 хв. & 30 хв. & 45 хв. & 55 хв. \\
\hline об'єктовий & 15 хв. & 30 хв. & 45 хв. & 55 хв. \\
\hline
\end{tabular}

Визначення НС, iï виду та рівня здійснюється згідно 3 Положенням про класифікацію НС, затвердженим постановою Кабінету Міністрів України від 15.07.1998 № 1099 та Класифікатором надзвичайних ситуацій ДК 019:2010.

Термінове повідомлення про надання медичної допомоги при НС заповнюється в лікувальному закладі, який бере участь у наданні медичної допомоги постраждалим при НС (у ФАП-і, поліклініці, амбулаторії, медико-санітарній частині, лікарні тощо, до яких звернулись постраждалі, станції Е(Ш)МД, що направила бригади до місця НС тощо), реєструється і 
передається негайно будь-яким доступним видом зв'язку в центральній районній лікарні (ЦРЛ) або міській центральній лікарні (ЦМЛ).

У ЦРЛ (ЦМЛ) черговий, відповідальний за функціонування підсистеми охорони здоров'я УІАС НС на цьому рівні, реєструє отриманий документ, підшиває його в справу i на підставі інформації документу та додаткової інформації про НС (якщо він iї має) заповнює в свою чергу бланк «Екстреного повідомлення про надання медичної допомоги при надзвичайній ситуації», відправляє його до вузла територіального органу управління охороною здоров'я (ТО УОЗ) та інформує про НС керівництво ЦРЛ (ЦМЛ). Аналогічно він діє отримавши інформацію про НС від інших джерел (від свідків НС, постраждалих, що звернулись в ЦРЛ за допомогою тощо).

Оперативний черговий ТОУОЗ, отримавши повідомлення 3 ЦРЛ (іншого медичного закладу), реєструє отриманий документ, підшиває його в справу і на підставі інформації документу та додаткової інформації про НС (якщо він іiі має) заповнює в свою чергу бланк «Екстреного повідомлення про надання медичної допомоги при надзвичайній ситуації», відправляє його до вузла МО3 України та інформує про НС керівництво ТО УОЗ. Аналогічно він діє отримавши інформацію про НС від інших джерел (від свідків НС, постраждалих, що звернулись в ЦРЛ за допомогою тощо).

Бази даних оперативно-координаційної диспетчерської служби включають:

нормативно-правову i довідкову інформацію щодо потенційно-небезпечних об'єктів та процесів (класифікатори, реєстри, паспорти тощо);

прогноз величини i структури санітарних втрат при виникненні НС на відповідній адміністративній території;

інформацію про поточний стан потенційно небезпечних об'єктів;

картографічну інформацію; 
оперативну i поточну інформацію про медико-санітарні наслідки при виникненні НC, їх динаміку та їх ліквідації;

оброблену та узагальнену аналітичну інформацію щодо НС та хід ліквідації іï медико-санітарних наслідків;

інформацію щодо відповідних методик прогнозування медико-санітарних наслідків НС тощо;

інформацію про сили і засоби ТЦ ЕМД та МК.

Здійснюється обмін інформацією між вузлами МO3 України, департаментами охорони здоров'я та цивільного захисту обласних державних адміністрацій, управлінням охорони здоров'я міських державних адміністрацій та іншими закладами охорони здоров'я. Залежно від масштабів i особливостей НС, що прогнозуються або виникли, обмін інформацією може відбуватися у режимі повсякденної діяльності, режимі підвищеної готовності, режимі діяльності за умов НС.

Оперативно-координаційна диспетчерська служба ТЦ ЕМД та МК працює у режимі повсякденної цілодобової діяльності при відсутності НС загальнодержавного і регіонального рівнів і загрози їх виникнення. У режимі повсякденної діяльності оперативно-координаційна диспетчерська служба обласної клінічної лікарні кожної доби на 05.30.год. подає до вузла МO3 України узагальнену інформацію про НС, що сталися за минулу добу на території області.

Оперативно-координаційна диспетчерська служба працює в режимі підвищеної готовності в разі істотного погіршення стану довкілля та ймовірної загрози виникнення НС загальнодержавного або регіонального рівнів техногенного та природного характеру.

Оперативно-координаційна диспетчерська служба здійснює наступні функції:

забезпечує цілодобову оперативно-чергову діяльність територіального вузла УІАС НС в підсистемі УІАС НC MO3 України; 
Науковий вісник: Державне управління № 4(6)2020

здійснює прийом, реєстрацію, накопичення, обробку та аналіз інформації, яка надходить до територіального вузла УІАС НС для підготовки управлінських рішень на регіональному рівні;

доводить отриману інформацію про медико-санітарні наслідки НС до керівництва департаментів охорони здоров'я та цивільного захисту обласних державних адміністрацій i подальші дії відповідно до «Плану медико-санітарного забезпечення населення при НС»;

забезпечує оперативну координацію дій медичних формувань територіальної служби медицини катастроф, інформаційну взаємодію між MO3 України, обласною державною адміністрацією, департаментами охорони здоров'я та цивільного захисту, установами і закладами охорони здоров'я області;

забезпечує постійний зв'язок та обмін інформацією 3 вузлом УІАС НC MO3 України, забезпечення можливості оперативного доступу та збереження інформаційного фонду;

надання оперативної та аналітичної інформації про наслідки надзвичайних ситуацій до вузла МО3 України за встановленими формами («Термінове повідомлення про надання медичної допомоги при НС» - форма 155/o), («Термінове повідомлення про надання медичної допомоги при НС уточнене або заключне» - форма № 155-1/о);

надання інформації до вузла МО3 України та до обласної державної адміністрації не пізніше четвертої доби після завершення ліквідації медико-санітарних наслідків НС за затвердженою формою звіту про надання медичної допомоги при НС («Звіт про надання медичної допомоги при НС» форма № 65-здоров та додаток дані про госпіталізованих п. 15.3);

надання інформації відповідно до Переліку НС до вузла УІАC HC MO3 України, передбаченого Регламентом, які відбулися на адміністративній території протягом місяця - до вузла МОЗ України за затвердженою формою Звіту («Звіт про 
Науковий вісник: Державне управління № 4(6)2020

надання медичної допомоги при НС що сталися на території» - форма № 66-здоров);

реєстрація повідомлень про $\mathrm{HC}$ в Журналі обліку інформації про надання медичної допомоги при надзвичайних ситуаціях, які надійшли з кожного лікувального закладу, який бере участь у наданні медичної допомоги постраждалим при НC - форма № 156/o;

надання до вузла МО3 України у режимі підвищеної готовності кожної доби о 05.30.год., 11.30.год. та 17.30.год. інформації про:

формування оперативних груп для вивчення обставин в районі можливого виникнення надзвичайних ситуацій та проведення підготовчих робіт по ліквідації медико-санітарних наслідків НС; запровадження цілодобового чергування членів координаційних комісій служби медицини катастроф та штабу департаментів цивільного захисту та охорони здоров'я;

приведення у стан підвищеної готовності наявних сил та засобів ДСМК відповідно до «Плану медико-санітарного забезпечення населення при НС», залучення (у разі потреби) додаткових сил, уточнення планів їх дії та переміщення в район можливого виникнення НС;

розробку i реалізацію комплексу заходів щодо захисту населення від медико санітарних наслідків НС та надання медичної допомоги в разі іï виникнення;

підготовку рекомендації для населення та його інформування щодо дій, які мають бути проведені для ліквідації медико-санітарних наслідків НС.

У разі виникнення або реальної загрози виникнення НС загальнодержавного та регіонального рівнів, компетентними органами державної влади запроваджується режим діяльності на певній адміністративній території чи на території всієї держави. При цьому режимі Оперативно-координаційна диспетчерська кожної доби о 05.30.год., 11.30.год., 15.30.год., 17.30.год. та 19.30.год. надає до вузла MO3 України інформацію про: 
виникнення медико-санітарних наслідків $\mathrm{HC}$ та меж території, на яких вони виникли;

заходи, що проводять органи управління охорони здоров’я по ліквідації медико-санітарних наслідків НС;

організацію і проведення робіт, пов'язаних 3 ліквідацією медико-санітарних наслідків НС із залученням відповідних сил i засобів, переміщення оперативних груп у район виникнення $\mathrm{HC}$;

заходи щодо забезпечення стабільної роботи закладів охорони здоров'я для медичного забезпечення постраждалого населення;

підготовку i доведення до населення інформації щодо вжитих заходів з медичного забезпечення і ліквідації медикосанітарних наслідків НС;

аналітичну інформацію про проведення робіт на окремих етапах i за весь період ліквідації медико-санітарних наслідків НС.

Організація взаємодії між ДСНС України і МОЗ України в разі виникнення надзвичайних ситуацій здійснюється відповідно до Інструкції [16].

Метою взаємодії ДСНС i MO3 3 попередження та ліквідації медико-санітарних наслідків НС $є$ забезпечення ефективного використання медичного персоналу, спеціалізованого санітарного транспорту, медичних виробів, лікарських засобів, закладів охорони здоров'я для рятування життя та збереження здоров'я людей під час ліквідації медикосанітарних наслідків НС.

Визначено, що взаємодія ДСНС і МО3 здійснюється на основі таких принципів:

єдині підходи до реалізації державної політики у сфері попередження та ліквідації НС, охорони здоров'я населення i профілактики захворювань;

пріоритет збереження життя i здоров'я населення при виникненні та під час ліквідації НC; 
Науковий вісник: Державне управління № 4(6)2020

єдині підходи i критерії під час прогнозування та оцінювання медико-санітарної обстановки за різних $\mathrm{HC}$, визначення можливостей рятувальних і медичних підрозділів, формувань та закладів.

ДСНС і МОЗ здійснюють взаємний обмін інформацією та оповіщення через відповідні відомчі оперативні служби 3 метою своєчасного доведення інформації про загрозу або виникнення НС.

Оповіщення та взаємний обмін інформацією організовуються на державному рівні між оперативночерговою службою державного центру управління в надзвичайних ситуаціях ДСНС (телефони: (044) 247-30-50, 59-01 (АТC-10), факс (044) 247-32-11, електронна пошта: oper@mns.gov.ua) та вузлом інформаційно-аналітичної обробки інформації МО3 України в Урядовій інформаційноаналітичній системі 3 питань надзвичайних ситуацій (оперативно-диспетчерський відділ ДЗ «УНПЦ ЕМД та МК MO3 України» (телефони-факси: (044) 518-57-08, 518-47-11, електронна пошта: disastermed2@ukr.net)).

Оповіщення та взаємний обмін інформацією на регіональному рівні організовуються між оперативнокоординаційними центрами територіальних органів ДСНС та структурними підрозділами 3 питань охорони здоров'я місцевих державних адміністрацій. Про зміни контактних номерів телефонів та адрес електронної пошти ДСНС та МОЗ негайно інформують один одного.

У форматі щоденного обміну інформацією:

1. Черговий оперативно-диспетчерського відділу Д3 «УНПЦ ЕМД та МК МОЗ України» щодня до 08:00 інформує оперативно-чергову службу державного центру управління в НС ДСНС про оперативну обстановку в межах компетенції $\mathrm{MO} 3$ щодо НС.

2. За запитом оперативно-чергової служби державного центру управління в НС ДСНС черговий оперативнодиспетчерського відділу ДЗ «УНПЦ ЕМД та МК MO3 


\section{Науковий вісник: Державне управління № 4(6)2020}

України» надає необхідні роз'яснення щодо переданої інформації.

У форматі оперативного інформування:

1. У разі отримання інформації про загрозу виникнення або виникнення НС та оперативної інформації про інфекційні хвороби, отруєння людей та інші медико-санітарні наслідки HC в межах компетенції MO3 черговий оперативнодиспетчерського відділу ДЗ «УНПЦ ЕМД та МК МО3 України» протягом 10 хв. інформує телефоном оперативночергову службу державного центру управління в НС ДСНС.

У випадку ускладнення ситуації на місці виникнення НС черговий оперативно-диспетчерського відділу ДЗ «УНПЦ ЕМД та МК MO3 України» негайно інформує оперативночергову службу державного центру управління в надзвичайних ситуаціях ДСНС для забезпечення оперативного реагування.

2. Усне інформування підтверджується протягом 1 год. на адресу електронної пошти оперативно-чергової служби державного центру управління в НС ДСНС або факсимільним зв'язком шляхом надсилання повідомлення про загрозу або виникнення НС та ліквідацію іiі наслідків і оперативної інформації про медико-санітарні наслідки НС.

3. У разі отримання оперативно-черговою службою державного центру управління в НC ДСНС первинної інформації про загрозу виникнення або виникнення НС у межах компетенції МО3 начальник чергової зміни державного центру управління в надзвичайних ситуаціях ДСНС протягом 10 хв. інформує про це телефоном чергового оперативнодиспетчерського відділу ДЗ «УНПЦ ЕМД та МК MO3 України».

У випадку ускладнення ситуації на місці виникнення НС оперативно-чергова служба державного центру управління в НC ДСНС негайно інформує чергового оперативнодиспетчерського відділу ДЗ «УНПЦ ЕМД та МК MO3 України» для забезпечення оперативного реагування.

4. За запитом оперативно-диспетчерського відділу Д3 
Науковий вісник: Державне управління № 4(6)2020

«УНПЦ ЕМД та МК МОЗ України» інформація про оперативну обстановку в районі виникнення НС черговою службою державного центру управління в $\mathrm{HC}$ ДСНС невідкладно подається факсимільним зв'язком або електронною поштою до оперативно-диспетчерського відділу ДЗ «УНПЦ ЕМД та МК МОЗ України».

У форматі періодичного оперативного інформування:

1. Інформування оперативно-диспетчерським відділом ДЗ «УНПЦ ЕМД та МК МОЗ України» оперативно-чергової служби державного центру управління в НС ДСНС про хід ліквідації наслідків НС здійснюється двічі на добу шляхом направлення інформації: до 20:00 станом на 18:00; до 08:00 станом на 00:00.

2. У разі утворення керівником робіт з ліквідації наслідків НC (далі - Керівник робіт) штабу з ліквідації наслідків НС (далі - Штаб з НС) залежно від рівня НС періодичність та форми оперативного інформування про ліквідацію наслідків НС можуть змінюватися відповідно до рішень Керівника робіт або начальника Штабу з НС.

3. У разі прийняття рішення щодо розгортання в державному центрі управління в надзвичайних ситуаціях ДСНС або у районі виникнення НС Штабу з НС за запитом начальника чергової зміни ДСНС черговий оперативнодиспетчерського відділу ДЗ «УНПЦ ЕМД та МК МО3 України» здійснює оповіщення керівництва МО3, яке входить до складу Штабу з НС.

4. ДЗ «УНПЦ ЕМД та МК МОЗ України» щотижня узагальнює інформацію центрів екстреної медичної допомоги та медицини катастроф адміністративно-територіальних одиниць про надзвичайні ситуації на території України та їхні медико-санітарні наслідки і надсилає іiі до ДСНС та МO3 за формою, наведеною в додатку_до Інструкції.

Висновки та напрями подальших досліджень. Життєво важливими є процеси прийняття управлінського рішення у НС, наприклад при виникненні пожеж, катастрофах, 
стихійних лихах, коли йдеться не тільки про оптимальне використання матеріальних та фінансових ресурсів, а в першу чергу про життя людей.

Зменшення часу на розроблення, прийняття та реалізацію управлінських рішень, зростання невизначеності та ризику, необхідність залучення 3 резервів додаткових ресурсів, наявність різних режимів функціонування системи державного управління в умовах НС свідчать про те, що державне управління у цій сфері має певні особливості. Їх урахування в діяльності органів державного управління в умовах НС дасть можливість зменшити вірогідність прийняття неадекватних управлінських рішень, сприятиме економії ресурсів та часу на ліквідацію наслідків НС, зменшенню людських втрат і збитків.

Слід зазначити, що проведення оцінювання якості запропонованих управлінських рішень необхідно проводити спираючись на інформаційно-аналітичне забезпечення, що передбачає збір та обробку оперативних даних із зони НС, та попередні розробки варіантів управлінських рішень 3 використанням математичного моделювання.

Звісно, що досягнення найкращих результатів у процесі опрацювання управлінських рішень з ліквідації наслідків НС можливо лише за умови поєднання методів, які визначаються рівнем проблеми та характером задач, що потребують вирішення.

Підсумовуючи слід зазначити, що опрацювання управлінських рішень в процесі ліквідації наслідків НС, зокрема медико-санітарних, як найбільш важких і важливих, потребує удосконалення не тільки завдяки використання сучасних інформаційних технологій i потужного математичного апарату, а особливо аналізу вітчизняного досвіду ліквідації НС та створення оперативних планів реагування на виникнення $\mathrm{HC}$ на всіх рівнях системи державного управління, що $є$ складовими інформаційного супроводу. 
Науковий вісник: Державне управління № 4(6)2020

Питання узгодженості обміну необхідною інформацією для прийняття управлінських рішень в умовах реагування на НC i визначення регламенту взаємного обміну цією інформацією стануть метою подальших наукових розвідок.

\section{Список використаних джерел}

1. Бакуменко В. Д. Прийняття рішень в державному управлінні: навч. посіб. [у 2 ч.]. Ч. 1. Теоретико-методологічні засади. К. : ВПЦ АМУ, 2010. С. 107-113.

2. Барило О. Г. Зарубіжний досвід створення інформаційноаналітичної системи цивільного захисту. Вісник Національного університету иивільного захисту Украӥни. Серія : Державне управління. 2017. Вип. 2. С. 387-395.

3. Барило О. Г. Інформація як складова системи державного управління у надзвичайних ситуаціях. Інвестиції: практика та досвід. 2011. № 2. С. 76-78.

4. Барило О. Г., Потеряйко С. П., Тищенко В. О. Підхід до вибору альтернативного рішення органами державного управління у надзвичайних ситуаціях. Економіка та держава. 2011. № 2. C. $124-126$.

5. Барило О. Г. Проблемні питання нормативно-правового забезпечення функціонування системи управління цивільного захисту. Аспекти публічного управління. 2017. Т. 5. № 11. C. 83-93.

6. Барило О. Г. Квашук В. П., Потеряйко С. П., Шойко В. А. Послідовність роботи органів державного управління у надзвичайних ситуаціях. Всеукр. наук.-практ. конф. рятувальників, 26-27 вер. 2012 р.: тези доп. К., 2012. С. 110-114.

7. Барило О. Г. Потеряйко С. П., Тищенко В. О. Удосконалення процесу управління у надзвичайних ситуаціях. Науковий вісник АМУ: збірник наукових праць. 2013. Вип. 2. С.119-124.

8. Ганцюк Т. Д. Інформаційне аналітичне забезпечення діяльності органів публічної влади в Україні: джерелознавчий аналіз дискурсійного поля. Державне управління: удосконалення та розвиток. електр. фах. вид. 2018. № 8. URL:http://www.dy.nayka.com.ua/pdf/8_2018/102.pdf (дата звернення 09.07.2020).

9. Котковський В. Інформаційно-аналітичне забезпечення прийняття управлінських рішень у діяльності органів державної влади. Теорія та практика державного управління. 2015. Вип. 4. C. $132-138$. 
Науковий вісник: Державне управління № 4(6)2020

10. Терент'єва А. В. Управління надзвичайними ситуаціями : монографія. К. : Доктор Медіа, 2009. 332 с.

11. Організація та управління процесом надання медичної допомоги постраждалим внаслідок землетрусів / Гур'єв С. О. та ін. Переяслав-Хмельницький: "СКД", 2008. 188 с.

12. Класифікатор надзвичайних ситуацій ДК 019:2010 // База даних «Законодавство України» / BP України. URL : https://zakon.rada.gov.ua/rada/show/va457609-10 (дата звернення 18.07.2020).

13. Кодекс цивільного захисту України : закон України від 02.10.2012p. № 5403-V1 // База даних «Законодавство України» / BP України. URL : https://zakon.rada.gov.ua/laws/show/5403-17 (дата звернення 19.07.2020).

14. Про затвердження Класифікаційних ознак надзвичайних ситуацій : наказ МВС України від 06.08.2018 № 658 // База даних «Законодавство України» / BP України. URL : https://zakon.rada.gov.ua/laws/show/z0969-18 (дата звернення 20.07.2020).

15. Про додаткові заходи щодо підвищення рівня інформаційного забезпечення ліквідації медико-санітарних наслідків надзвичайних ситуацій природного техногенного характеру : наказ МО3 України від 30.07.2009 № 560 // База даних «Законодавство України» / BP України. URL : https://zakon.rada.gov.ua/rada/show/ru/v0560282-09 (дата звернення 20.07.2020).

16. Про затвердження Інструкції щодо організації взаємодії між Державною службою України 3 надзвичайних ситуацій i Міністерством охорони здоров'я України в разі виникнення надзвичайних ситуацій : наказ МВС України та МОЗ України від 03.04.2018 № 275/600. // База даних «Законодавство України» / ВP України. URL : https://zakon.rada.gov.ua/laws/show/z0479-18 (дата звернення 20.07.2020).

17. Про затвердження Правил санітарної охорони території України : постанова Кабінету Міністрів України від 22.08.2011 № 893 // «Законодавство України» / BP України. URL : https://zakon.rada.gov.ua/laws/show/893-2011-\%D0\%BF\#Text (дата звернення 20.07.2020). 


\section{References}

1. Bakumenko V. D. (2000), Formuvannia derzhavno-upravlins'kykh rishen': problemy teorii, metodolohii[Formation of managerial decisions: problems of theory and methodology. Practice], UAPA Publishing, Kyiv, Ukraine.

2. Barylo O. H. (2017). "Foreign experience in creating an informationanalytical system of civil defense". Visny`k Nacional'nogo universy`tetu cy`vil'nogo zaxy`stu Ukrayiny`. Seriya : Derzhavne upravlinnya. vol. 2. P. 387-395.

3. Barylo O. H. (2011), "Information as a component of the system of public administration in emergencies", Investy ciyi: prakty ka ta dosvid. № 2. P. 76-78.

4. Barylo O. H., Poteriaiko S. P., Tyshchenko V. O. (2011). "Approach to the choice of alternative solutions by public administration bodies in emergencies". Ekonomika ta derzhava. № 2. P. 124-126.

5. Barylo O. H. (2017). "Problematic issues of regulatory and legal support for the functioning of the civil protection management system”. Aspekty` publichnogo upravlinnya. vol. 5. № 11. P. 83-93.

6. Barylo O. H., Kvashuk V. P., Poteriaiko S. P., Shoiko V. A. (2012). "Sequence of work of public administration bodies in emergencies". K., 2012. P. 110-114.

7. Barylo O. H., Poteriaiko S. P., Tyshchenko V. O. (2013). "Improving the management process in emergencies". Удосконалення процесу управління у надзвичайних ситуаціях. Naukovy j visny`k Akademiyi municy pal nogo upravlinnya. vol. 2. P. 119-124.

8. Hantsiuk T. D. (2018). "Information and analytical support of public authorities in Ukraine : source analysis of the discourse field". Derzhavne upravlinnya : udoskonalennya ta rozvy tok. № 8. URL : http://www.dy.nayka.com.ua/pdf/8_2018/102.pdf (Accessed 09 July. 2020).

9. Kotkovskyi V. (2015). "Information and analytical support of management decisions in the activities of public authorities". Teoriya ta prakty ka derzhavnogo upravlinnya. vol. 4. P. 1132-138.

10. Terentieva A. V. (2009). Upravlinnya nadzvy`chajny`my` sy`tuaciyamy [Emergency management]. Dotor Media. Kyiv, Ukraine. 


\section{Науковий вісник: Державне управління № 4(6)2020}

11. Huriev S. O. and at. (2008). Organizaciya ta upravlinnya procesom nadannya medy`chnoyi dopomogy` postrazhdaly`m vnaslidok zemletrusiv [Organization and management of the process of providing medical care to earthquake victims]. PereyaslavKhmelnytsky, Ukraine.

12. Classifier of emergency situations DK 019: 2010. URL : https://zakon.rada.gov.ua/rada/show/va457609-10

(Accessed 18 July 2020).

13. The Verkhovna Rada of Ukraine (2012), The Law of Ukraine "Code of Civil Protection". URL https://zakon.rada.gov.ua/laws/show/5403-17

(Accessed 19 July 2020).

14. Ministry of Internal Affairs of Ukraine (2018). Order of Ministry "About the statement of Classification signs of emergencies". URL : https://zakon.rada.gov.ua/laws/show/z0969-18

(Accessed 20 July 2020).

15. Ministry of Public Health of Ukraine (2009). Order of Ministry "About additional measures for increase of level of information maintenance of liquidation of medical and sanitary consequences of emergencies of natural technogenic character". URL : https://zakon.rada.gov.ua/rada/show/ru/v0560282-09

(Accessed 20 July 2020).

16. Ministry of Internal Affairs of Ukraine and Ministry of Public Health of Ukraine (2018). Order of Ministry "On approval of the Instruction on the organization of interaction between the State Service of Ukraine for Emergencies and the Ministry of Health of Ukraine in case of emergencies". URL https://zakon.rada.gov.ua/laws/show/z0479-18

(Accessed 20 July 2020).

17. Pro zatverdzhennia Pravyl sanitarnoi okhorony terytorii Ukrainy : postanova Kabinetu Ministriv Ukrainy vid 22.08.2011 № 893 // «Zakonodavstvo Ukrainy» / VR Ukrainy. URL : https://zakon.rada.gov.ua/laws/show/893-2011-\%D0\%BF\#Text (data zvernennia 20.07.2020). 


\section{INFORMATION INTERACTION IN THE CONDITIONS OF EMERGENCY SITUATIONS OF MEDICAL AND BIOLOGICAL NATURE}

Huriev Serhii, Dr. Sc. (Med.), Prof., Deputy Director of Science, State Institution "Ukrainian Scientific and Practical Center for Emergency Medical Care and Medicine Disasters of The Ministry of Health of Ukraine, 02660, Kyiv, Bratyslavska str., 3, tel.: (044)-518-57-08, e-mail: disastermedukrpost.ua https://orcid.org/0000-0003-0191-945X,

Iskra Nataliia, Dr. Sc. (Med.), Assoc. Prof., Professor of the Department of Disaster Medicine and Military Medical Training, Shypyk National Medical Academy of Postgraduate Education, 02660, Kyiv, Bratyslavska str., 3, tel. (044)-518-57-08

Terentieva Anna, Dr. Sc. (Pbl Adm.), Prof., Head of the Department of Public Administration in the sphere of civil protection, Institute of Public Administration and Research in Civil Protection, 01011, Kyiv, Rybalska Str., 18, tel. (044)468-9184, e-mail: teren_a@ukr.net, https://orcid.org/0000-0003$\underline{3881-5865}$

The basic resource for the implementation of management activities, in particular the development of management decisions, is adequate information about the emergency as an event and its characteristics. This information is based on the following measures for the implementation of management functions: assessment of the situation in the emergency zone, decision-making management, action planning, organization of interaction and crisis communications, setting tasks for the implementation and control of management decisions.

The problem of obtaining adequate and timely information about the consequences of an emergency directly from the area for management decisions often arises due to the lack of established procedures for obtaining and exchanging information between all emergency services involved in assisting victims. The solution to this problem is possible only in the presence of consolidated approaches to the classification of the emergency, methods for determining the rotary and irreversible sanitary losses and the calculation of forces and means involved in the elimination of the consequences of the emergency.

The purpose of cooperation between the State Emergency Service of Ukraine and the Ministry of Public Health to prevent and eliminate the health consequences of an emergency is to ensure the effective use of medical personnel, specialized ambulances, medical devices, medicines, health care facilities to save lives and health during medical and sanitary consequences of emergency.

Key words: information interaction, management, consequences, emergency, message. 